\title{
RE-READING SAHITYA AND LITERATURE AND THE PROBLEMS OF SINGULARITY
}

\begin{abstract}
The terms "Sahitya" and "Literature", though apparently synonymous, have a more nuanced meaning as sahitya-as-literature and literature-as-sahitya. In a critical inspection of the two terms, a deeper truth can be uncovered in a re-reading of sahitya. The proposed study will engage with unpacking the term sahitya and show how it underscores the "unity of vision" as a major component of literature. It also provides a space for the understanding of postcolonial scholarship, challenging what is designated as "Third-World Literature". An attempt will thus be made to analyse sahitya from the point of view of the poet-thinker Rabindranath Tagore, who said: The word "sahitya" comes from "sahit" [together/togetherness], and "we find in the word sahitya the idea of a union".
\end{abstract}

Key words: Rabindranath Tagore, Sahitya, Literature, "Third World Literature"

\section{Introduction}

A piece of writing may start off life as history or philosophy and then come to be ranked as literature; or it may start off as literature and then come to be valued for its archaeological significance. Some texts are born literary, some achieve literariness, and some have literariness thrust upon them. Breeding in this respect may count for a good deal more than birth. What matters may not be where you came from but how people treat you. If they decide that you are literature then it seems that you are, irrespective of what you thought you were. (Eagleton 1996: 7-8)

Given the nature of preconditions for the field of literature and the study of literature, it is perhaps useful for this current exploration to start with and glean from Fredric R. Jameson, one of the important contemporary theorists in the field of literary culture. In his contextual study of the First World's reading of the categorized Third World Literature, Jameson provides a radical critique of the canonical vs. the non-

* Department of English, The Neotia University, Jhinga, Sarisha, DH Road, 24 Pgs (S), West Bengal, India; e-mail: dipannitadatta@gmail.com,dipannita.datta@tnu.in 
canonical forms of literature and observes in his 1986 essay "Third-World Literature in the Era of Multinational Capitalism":

Many arguments can be made for the importance and interest of noncanonical forms of literature such as that of the third world, but one is peculiarly self-defeating because it borrows the weapons of the adversary: the strategy of trying to prove that these texts are as "great" as those of the cannon itself. (Jameson 1986: 65)

As this extract reveals, Jameson talks from a "humanist"1 perspective, for he raises the question of how the discriminatory mechanism of the First World operates in the changing world of literature pervasively. However, Jameson's language of contestation and comparison between non-canonical forms of literature of the Third World and great forms of literature as those of the "canon itself", in the essay under consideration, especially, is not as simple as it may seem. Making his "object" clear, he observes:

Nothing is to be gained by passing over in silence the radical difference of non-canonical texts. The third-world novel will not offer the satisfactions of Proust or Joyce. (Jameson 1986: 65)

This comment on non-canonical texts of the Third World, which surely presupposes the singularity of modern culture and its synonym progress, is crucial to this essay titled "Re-reading Sahitya and Literature". For, Jameson allows a significant space of open discussion on how the forces of " "pure" "modern" culture continue to operate from the top in an increasingly global society, as it were during the colonial times (for example, India under the British regime). Moreover, keeping the meaning of "Third World Literature" intact as a "foreigner" to the "First World" Jameson insists on the word "non-canonical" such as that of the "third world". These oppositional terms the "First World" and the "Third World", the "canonical" and the "non-canonical" demonstrate the continuity of the proactive violent reality in our contemporary times. This essay attempts to examine from the position of an imposed subjugation/marginalization or as it is said "from below" the ways certain tendencies of the colonizer-colonized/domination-subordination mechanism were maintained in the ex-colonies in the so-called modern era under the aegis of colonial imperialism. There will also be an attempt to address: How the subjugated resists the brutal effect

${ }^{1}$ See Danius. 
of "singularity" - of a structure with harsh binaries, such as power and powerlessness, and dis(mantles) the meaning of the categorized "non-canonical texts" (read as non-canonical literature) of the so-called "Third World" and un(settles) the singular imperialist ideology of domination-subordination without ignoring its inherent violent structures?

From a postcolonial perspective, looking back into the ongoing pandemic mechanisms of neocolonialism and its disparagement in the area of literary culture, it is worth mentioning that veiled by the word "Literature", the meaning of "togetherness" in sahitya (loosely translated as literature) has received little scholarly attention and remains relatively unknown to the world of literatures. Given the nature of the dis(continuous) relationship between colonialism and neocolonialism, the brutal difference between the First World and the Third World and by extension the "canonical texts" and the "non-canonical texts", a re-reading of an entirely newly recovered "reality", free of colonial taints, is required across the limits of nation and geography. In other words, a process of decolonization is an imperative.

The present study, while remaining engaged with the term sahitya, explores how far the "unity of vision" as suggested by Tagore forms a major component of creativity and contributes to humanity through the process of "decolonization", both artistic and literary. Furthermore, the continuing significance of Tagore's philosophy of aesthetics including his literary imagination (powers of invention, vision, creation and creativity) will be the subject of this argument in order to understand the meaning of sahitya/ literature in today's world of perpetual violence and polarization.

\subsection{Literary imagination and Sahitya}

Drawing on the links between colonialism/imperialism and codes of the dominant European discourses and its alleged/assumed superiority, Helen Tiffin, an influential postcolonial theorist and a writer of literary studies, shows the ways colonial discourse theory, with its basis in European philosophy, undermines the politics of anti-colonial pedagogy within the academies, and how literature (produced from/in the ex-colonies) and its meaning consequently tends to get obfuscated and concealed within the complexities of center and periphery. Analyzing the continuity of this problematic area in the contemporary First World academia, she insists on the connotation of decolonization for it "invokes an ongoing [postcolonial] dialectic between hegemonic centrist systems and peripheral subversion of them" (Tiffin 2006: 99). Read from a twenty-first century post postcolonial socio-cultural, historical and literary perspective, this analysis of Tiffin, though observed from a slightly different

\footnotetext{
${ }^{2}$ For a detailed reading of various debates that churned around the topic, readers may see Attridge 2004.
} 
context, takes us to the heart of the argument in this study. It provides us with a discursive scope to investigate the means by which the colonial regime imposed its dominant codes on the colonies and continued to maintain its strategy of polarizing the world into the West and the rest, and the means by which a postcolonial subversion and appropriation of the dominant European discourses became possible.

In this regard, I would like to refer to the "world poet" (visvakavi) Rabindranath Tagore (1861-1941). As early as in 1895, Tagore said: "The word sahitya [...] comes from sahit [together]. Hence, if we take into account its etymological sense, we find in the word sahitya the idea of a union. It is not simply a union of idea and idea, language and language, book and book" (Tagore 1895: 179). It moves beyond these parameters establishing links between far and near, between past and present, and, importantly establishes an intimate connection between one person and another. Responding to the nature of the dichotomous relationship between colonizer and colonized, he insisted further and said that "the people of a country deficient in literature have no vital bonds to join them: they remain isolated" (Tagore 1895: 179).

What is Literature (with capital L) then vis-à-vis the literary canon? Any attempt to presume a simple answer to that would be emptying the meaning of Literature and that of the creation of the canon of all conflicts. It also seems to me dogmatic not to consider the (im)possibility that creation of the canon might stem from. In fact, for the specific purpose of this essay, to unveil the nuanced meaning of "sahitya-as-literature and literature-as-sahitya" in relation to specific social condition is crucial; the task demands an understanding of how the process of displacement and appropriation of the cultural obligations operates within and without the third world, the ways "noncanonical texts" and/or non-canonical literature get categorized, and the efforts of the stakeholders of the non-canonical space on the face of several impediments.

At this juncture, it is best to return to and locate Jameson's claims that "the radical difference of non-canonical texts" and "the third-world novel will never offer the satisfactions of Proust or Joyce" (Jameson 1986: 65). The essay "Third-World Literature in the Era of Multinational Capitalism" does not provide an explanation as to what is Third World novel/literature? What is the difference between non-canonical and canonical texts? Who decides what is canonical and what is not a canonical text? What kind of pleasure is expected of the so-called non-canonical texts? Why to attain the level of the canonical/ First World canon is imperative at all? Is it possible to transcend the difference between canonical and non-canonical texts when claims of superiority of canonical texts over non-canonical texts are already established, and even veiled or hidden within the historical structures of domination?

Any attempt to comment on or gloss over these complex issues, let alone analyzing them, at the least requires that we first clarify the etymological difference between 
sahitya and literature. As mentioned above, sahitya is a Sanskrit term for literature, and it is derived from the word sahita, which carries the sense of "togetherness", "association" etymologically. Moreover, sahitya is not confined just to written text/ literature. The etymology of the English word "literature" for the greater part of its history being derived from lit(t)eratura and its Latin root "lit( $(t)$ era" or "letter" refers to any written works and accounts or all writing formed with letters, though the word literature has gradually evolved, connoting both written as well as oral texts. However, due to lack of a synonym or a suitable word for sahitya in the English language that would bring out its meaning, in this essay the word literature (read as sahitya) will be used in this sense along with sahitya to explore how far disparate elements combine together and contribute towards its meaning. I would also like to mention here that this essay will not deal with a particular novel or a particular literary piece. For, in an increasingly globalizing scenario, re-visiting the categorized homogenous term Third World literature collective, as Jameson maintains it, is necessary. The essay, while unpacking the term sahitya attempts to investigate the relationship between "idea of a union" and the "unity of vision" which underlines and contributes towards its meaning. It will also attempt re-reading multiple truths of creation and creativity in sahitya/literature which might make communication possible and help in transforming the polarized common human condition.

\subsection{Sahitya beyond boundaries}

In Paribarik Smritilipi Pustak (family album/memory book) ${ }^{3}$ Tagore wrote:

The essence of literature does not allow itself to be trapped within a definition. It is like the essence of life [...] Life is generated by life, fire must be lit from fire - so too living literature is born when vitality flows out of a pen from the poet's inmost soul.

Shakespeare gave birth to his dramatis personae from within his own vital being: not his intelligence, nor his moral piety, nor even his feelings, but from his life cells girt round with all the human functions and faculties. There is in literature the idea of creation [...] [D]uring creation, [the] inert materials seem endowed with consciousness by some novel principle, so that they fashion themselves by their own force- as though they are linked up with their own veins, letting the vital power flow easily through them [...] [T] hat vital power, as enshrined in literature, can enter the hearts of all humankind for all time (Tagore 1889: 49-50).

\footnotetext{
${ }^{3}$ For further reference, readers may see, Das and Chaudhuri 2001.
} 
Rabindranath Tagore, the first "world poet" in modern India, repeatedly addressed literature as "intimate experience" of interconnected and interlocked whole - "a unified whole" - in many of his lectures and writings, almost systematically since 1889 , and the need for perceiving a "unity of vision" in the interpretation of sahitya, even in the face of scorns and threats from traditionalists and modernists alike. Responding to the large amount of capitalist penetration in British India and the way the aggressive outside atmosphere was influencing the literary activity in the day-to-day life of the subject people, including different men and women in a "highly diverse plural society", he attempted negotiating the micropolitics of everyday experience, the strategic importance in binding the immediate everyday life to distant and future macrostructures of life. Again, while identifying the winds of change and exposing the unsettling aspects of the transition (a part of capitalist modernity), he told his modernist countrymen in Bengal: "The criticism of [sahitya] literature consists in its interpretation and not simply its analysis" (Tagore 1936: 6). This literary exercise of Tagore, put into practice in his diverse fields of activities, including educational and social reforms, made the Bengali poet, essayist and literary critic Sudhindranath Datta (1901-1960) succinctly observe: "Unless the modernists realise the essence of Rabindranath they will not be able to understand themselves" (Sanyal 2009: 191), emphasizing the uselessness of exerting the contradictions between the self/host and the other/guest/stranger/enemy/foreigner. Datta is right, for Tagore suggests an alternative discourse on interpreting traditional ways of reading literature rooted in a distinctively civilizational concept of universalism. In fact, Tagore locates an eighth century Indian poet-scholar Bhabhabhuti in the world of literature, and writes:

Neither self-interest nor fame but [the presence of] the endless time and the vast world [that enables literature to link] one human being to another, one age to another with the bonds of life. [...] This is because [...] one of the main ingredients of literature is union or contact. (Tagore 1895: 184)

Sahitya then is a tool to achieve unity and togetherness, and the role of sahitya in society is a dynamic exercise of understanding humankind in a cross-cultural sense in its deepest resources, which "reconciles the phenomenal world and the human personality" in the mind of the creator (Das 2001: 13). It speaks of the different forms and ways of expression in different literary genres and in a particular literary piece across the limits of (dis)continuous time and how different people from different geographical spaces interact with each other and takes its form in the mould of man's/ creator's perception. That is, the urge for self-expression is delimited. It is surrounded/ encircled by several external factors. Tagore writes: 
In a society where ideas are constantly gathering in people's minds and stirring them, where mental contact with each other allows many forms of mutual empathy, ideas from the friction of minds and literature from the friction of ideas $[\ldots]$ are engendered and dispersed [one cannot operate in isolation from another] (Tagore 1895: 184).

Such an unstructured "hybrid" anti-colonial/anti-imperial perspective is like "writing with scars of a hybrid register" (Chaudhuri 2001: vi), to use the words of distinguished literary scholar Sukanta Chaudhuri. Indeed, Tagore with a lucid grace presents sahitya to the world of literatures and its potential to contribute to the decolonization process without negating the West. Unfortunately, the West has categorized itself as the First World and its literary production as the First World canon. Thereby, the Third World is maintained as the non-canonical, the "Other" of the First World canon. In Tagore's time the First World was the West and the Third World the East. Therefore, it must be understood that the "national allegory" that features in Jameson's 1986 essay "Third-World Literature in the Era of Multinational Capitalism" is an invention of the West. It also shows how literary canons are constructed and how literary texts get canonized in "different" and "invidious" ways, though Jameson shifts his reading from the canons to national allegory. Even in this, as Aijaz Ahmad, an acclaimed postcolonial literary theorist and theorist of modern history, politics and culture, responding to Jameson observes, "it also becomes possible to see that allegorisation is by no means specific to the so-called Third-world" (Ahmad 1987: 15).

In this context, it is relevant to recall Edward Said, a proponent of postcolonial cultural theory. In his response to imperialism, its binary nationalism and "the massive edifice of Western empire" and the revision that has taken over by the anti-imperial activities he writes: "Cultures are not impermeable". For, history of all cultures is the history of cultural borrowings. He insists that this is a universal norm, and adds to it: "Who has yet determined how much the domination of others contributed to the enormous wealth of the English and French states?" (Said 1994: 217; Said 2006: 98). This of course does not directly answer the questions he raised on the "cultural oppositions" between the First World and the Third World (or the changing equation between the West and the East/the rest/the non-West and the significance of the genuine dominant version of nationalism that took its final shape in the nineteenth century, impacted India and shaped Indian thoughts within the overarching atmosphere of colonialism). The production of modern cultures and the "hegemonic centric systems" (Tiffin 2006: 99) of the exclusive literary canons of the rulers, in fact, to a great extent survived on the experiments with the periphery or the subject people. Here the observation of the English poet Mathew Arnold (1822-1888), also known for his cultural and literary criticism, is crucial. He wrote in 1848: 
How plain it is now [...] that England is in a certain sense far behind the Continent. In conversation, in the newspapers, one is so stuck with the fact of the utter insensibility [...] Our practical virtues never certainly revealed more clearly their isolation. I am not sure but I agree in Lamartine's prophecy that 100 years hence the Continent will be a great United Federal Republic, and England all her colonies gone, in a dull steady decay. (Russel 1900:10)

It is clear that nineteenth-century England was in need of literary thoughts in order to strengthen their control over the colonies. Arnold, in fact, makes his objective clear when he states "England is in certain sense far behind the Continent". Arnold's words, and that he was thinking in terms of imperial power, drew Tagore's attention and he referred to it in several of his essays and directly to Arnold in his essay "Sahityer Saundarya" (The Beauty of Literature) written during late 1890 (approximately) and later in "Sahityatattwa" (The Philosophy of Literature) in 1934. This aspect of literature remained unattended in Arnold's rich work on literary criticism ${ }^{4}$. What is of importance here is the borrowing-lending interface of reality in cultural interactions, a reality that, echoing T.S. Eliot, as Said observes, cannot be deprived of the "other echoes [that] inhabit the garden" (Said 1994: 336).

Tagore's insight into sahitya is one such garden populated with a variety of disparate elements, such as, shabda (sound and word), artha (meaning) of the ancient (oral literature) and the Indian classical tradition as described in the Kavyalankar (Ornaments of Poetry) of the seventh-century Sanskrit poetics of Bhamaha. Tagore extends the meaning without criticizing it through interpretation by going beyond the relation of sound and sense to a larger human relationship. In fact, Tagore's position in the lineage of the scholarly tradition of Indian poetics is that of a rescuer and doer. A clue to the historiographical "consummation" and "decline" of Indian poetics would be useful here. After the tenth or eleventh century, the intellectual vigour of the tradition slowly began to decline and reduced to barren exercises in ingenuity (Das 2001: 3). The failure, as Sisir Kumar Das, a Tagore scholar and a notable figure among Indian literary historiographers, observes, lay in the inability of the tradition "to go beyond Sanskrit to the literatures produced in the living languages of the country". Until the mid-nineteenth century, except for some sporadic instances of critical analysis, there was no criticism at all in most Indian languages, including Bengali; the efforts for literary interpretation was not in vogue (Das 2001: 3). Moreover, the Bengali intelligentsia, or, the English-educated Bengali literati showed little interest in Indian literary theory.

\footnotetext{
${ }^{4}$ For details readers may refer to Sahitya (Literature), 1924 in Das and Chaudhuri (2001: 258-264). Also see, Sahitya (2004).
} 
Even Bankimchandra Chattopadhyay (1838-94), a literary critic and novelist who was almost universally held to be a champion of Hindu nationalism, in 1873 dismissed Sanskrit poetics in general and the theory of $\mathrm{rasa}^{5}$ in particular with unconcealed contempt. His comments on the Sanskrit poem Gitagovinda demonstrate the indolence of his contemporary society, which suffered from a strong sense of defeatism. However, one cannot ignore his belief in beauty, an important component of literary creation and his contribution to the life of new Bengali literary criticism by underlining strongly the importance of a sociological approach to literature. He also hinted at the possibility of exploring the creative process by privileging the author's mind and personality. As Das observes: his "understanding of the poet is no less important than that of the poetry" and that opened up a new horizon in Bengali critical thought (Das 2001: 5-6). Rabindranath Tagore, a younger contemporary of Bankimchandra, acknowledged the historical role played by his immediate predecessor in the area of intellectual enquiry in his 1907 slender volume on Adhunik Sahitya (Modern Literature). In this volume of sixteen essays, he also discovered a new voice in the poet Biharilal Chakrabarti (183594). Though inspired by English poets, Biharilal did not fail to refer to the theory of rasa as opposed to Michael Madhusudan Dutt (1838-94), who hardly showed any interest in Indian literary aesthetics or in Indian literary theory.

\subsubsection{Sahitya and the literary theory of togetherness and connection}

Tagore of course was familiar with European aesthetics and criticism, but he privileged neither the European academic approach to art and literature nor the Sanskrit poetics, in particular, the literary theory of rasa. He rather took a difficult in-between path, creating a "Third" space for the self, for self-expression and for all human race while ensuring that sahitya not only links the relationship between human beings but also opens possibilities of bringing them closer to one another. This concept

\footnotetext{
${ }^{5}$ Rasa (Sanskrit: "essence", "taste", or "flavour", literally "sap" or "juice"), Indian concept of aesthetic flavour, is an essential element of any work of visual, literary, or performing art that can only be suggested, not described. It is a kind of contemplative abstraction in which the inwardness of human feelings suffuses the surrounding world of embodied forms. Rasa literally means taste or savour, and, as used to denote the essence of poetry, it signifies the peculiar experience that poetry affords us. See Chaudhury (1965: 145-149). The theory of rasa is attributed to Bharata, a sage-priest who may have lived sometime between the first century BCE and the third century CE. It was developed by the rhetorician and philosopher Abhiinavagupta (c. 1000), who applied it to all varieties of theatre and poetry. The principal human feelings, according to Bharata, are delight, laughter, sorrow, anger, energy, fear, disgust, heroism, and astonishment, all of which may be recast in contemplative form as the various rasas: erotic, comic, pathetic, furious, heroic, terrible, odious, marvellous, and quietistic. These rasas comprise the components of aesthetic experience. The power to taste rasa is a reward for merit in some previous existence. (See https://www.britannica.com/art/rasa) For further reading on rasa theory, readers may see, for example, Gnoli (1985), The Aesthetic Experience; Higgins (2007), "An Alchemy of Emotion".
} 
of "togetherness" being central to Tagore's literary theory, it is worthy to note here, as mentioned earlier, Tagore's contribution to the world of literature and in literary aesthetics or in Indian literary theory lies in transforming the Sanskrit classics to the literatures produced in the living Bengali language of the country. He showed the importance of rasa (or his emphasis being on the ultimate impact) in Sanskrit poetics that Bankimchandra dismissed. Though his use of the term is quite general, it is worth mentioning here about the Prachin Sahitya (Ancient Literature), another set of essays Tagore wrote in 1907. In these essays Tagore not only retrieved the great Sanskrit texts from the morass of mere rhetorical commentary to present them as living works, but also he dealt with some of the important texts of Sanskrit Literature, such as the Ramayana, Kalidasa's Kumarsambhabam, Abhijnanashakuntalam and Meghdutam and Banabhatta's Kadambari in a way that their presence is still alive and beautiful, capable of speaking to the readers of modern times. The essays in general are considered as the best demonstration of Tagore's critical and interpretive power and insight. The poet Kalidasa, who Tagore most admired, for the first time appears before the modern reader as a poet of great imagination and power, his voice still fresh and vibrant. As Sisir Das perceptibly observes: "[Tagore] does for Sanskrit literature what European classicists had done for Greek and Latin, renewing them for the modern sensibility [through critical analysis] in Modern European languages" (Das 2001: 8).

Equally significant are his 1907 essays collected in Loksahitya (Folk Literature), which contains Bengali nursery rhymes and rural literature. In this collection, to put it very briefly, he discovered the great beauty and depth of the oral and written literature of/from the margins and offered this neglected area of literature to his countrymen, indifferent and ignorant of their literary heritage. It was not to prove any relationship between the peasants of Bengal and their white masters. In fact, for the first time in Indian literature the subaltern was valorized (Das 2001:10).

To this rich wealth of literature of the Tagorean oeuvre one should add the poet's profound interest in and veneration for the Buddha and his thought, and his evolving creative response to Buddhism. He was also a great admirer of the abundance and variety of the Shakespearean world, though he gradually became apprehensive of the Shakespearean model. It was neither because of any cultural chauvinism nor was it because of the emergent Hindu nationalism coloured by revivalist prejudices. The gradual change took place in his critical writings because his conception of drama changed with time. His response to Sanskrit literature emerged from "an ambience created partly by European Romantic theories of poetry [as in Shelley and Coleridge and Goethe] and partly by the Arnoldian view of poetry as a criticism of life" (Das 2001: 8). He was equally innovative in foregrounding certain neglected characters in Sanskrit literature. Last but not least was his deep admiration for the non-canonical and 
marginal literature in which he discovered great beauty and depth, to which particularly the Indian elites were totally oblivious (10). Simultaneous with his principles of sahitya which are imbued with the presence and absence of even the last person in the society, was his aesthetic experience of joy which led him to the attainment of higher forms of experience inclusive of even the smallest of small nations, such as Serbia designated as eastern, the lesser East of the West. As evident, Tagore's approach to literature was holistic. In all, his was a defence of and the acceptance of a plurality of interpretations ${ }^{6}$. In fact, while trying to link the planetary Earth in its various manifestations and the world life, or in his own usage of the metaphor (sima, the boundary, the finite) and (asim, the boundless, the infinite) the poet contributes to an inclusive approach to mankind, which is not independent of the historical implications of reality, here, particularly, the European colonial enterprise. But Tagore's expression of art and literary theory is a response of the creative soul/mind to the call of the real. "It is not imitation of external reality but a response to that reality". In this sense, sahitya is an instrument to attain ananda, joy, the "savour" or perception of the supreme reality, and it reminds us of the famous declaration of T. S. Eliot that "the greatness of literature cannot be determined solely by literary standards". It dismisses and establishes what Jameson observes as the First World "strategy" of trying to prove that [their] texts are as "great as those of the canon itself" as opposed to the categorized Third World and its heterogeneous field of literature. For, as Jameson himself insists, the dominant agent of determining literary standards is "predominantly western machineries". In this context, Tagore's theory of sahitya may be read along the lines of Aijaz Ahmad who responds to Jameson underlining the meaning of a humanist "not humanist in the bourgeois sense; but equally surly, encompassing humanity in general" (Ahmad 1994: 316). If this boundless aspect sounds too critical, in the words of Abu Sayed Ayyub, Tagore's interpretation of literature and his aesthetic philosophical thought "emerges as the notion that art is a bridge across the chasm which normally separates the individual from the world around" (Ayyub 1961: 81; Das 2001: 16). Sahitya, then is an instrument to achieve togetherness and connection. In its deepest unison with the whole world, the "togetherness" that draws Tagore to the idea of literature as communication and expression, sahitya creates harmony with the mind of all humanity and connections with the world, transgressing the boundary of the self and the other, the East and the West, and Eastern Europe projected as the "other" Nation of Europe. "Re-membering", to use the term of Homi K. Bhabha, the past into the present, ancient times into modern times, and connecting the distant and the near, sahitya offers limitless possibility to

\footnotetext{
${ }^{6}$ For more on Tagore in Serbia and how the interplay of consent and coercion, which constitutes the "nature of the controls", are placed on the production of discourse and interpretation of literary-cultural interaction, see Datta (2016: 105-118).
} 
exchange ideas with one country and another, creating spaces for the aesthetic power, of artistic enjoyment that conveys delight and opens into the broader universe beyond the nation. However, problems of singularity vis-à-vis literature continue.

\section{References}

Ahmad, A. (1987). Jameson's Rhetoric of Otherness and the "National Allegory". Social Text, 17(15), 3-25.

Ahmad, A. (1994). In Theory: Classes, Nations, Literatures. London: Verso.

Attridge, D. (2004). The Singularity of Literature. New York: Routledge.

Ayyub, A. S. (1961). The Aesthetic Philosophy of Tagore. In: Rabindranath Tagore Centenary Volume, New Delhi: Sahitya Akademi, 78-87.

Bhabha, H. K. (1994). The Location of Culture. New York, NY: Routledge.

Chaudhuri, S. (2001). Preface. In: S. K. Das and S. Chaudhuri (eds.), Rabindranath Tagore: Selected Writings on Literature and Language, New Delhi: Oxford University Press, v-viii.

Chaudhury, P. J. (1965). The Theory of Rasa. The Journal of Aesthetics and Art Criticism 24(1), Autumn 1965, Supplement to the Oriental Issue: The Aesthetic Attitude in Indian Aesthetics: Pravas Jivan Chaudhury, 145-149.

Danius, S. (undated). About Fredric R. Jameson. (31 May 2019)

$<$ https://www.holbergprisen.no/en/fredric-r-jameson/about-fredric-r-jameson.html $>$.

Das, S. K. (2001). Introduction. In: S. K. Das and S. Chaudhuri (eds.), Rabindranath

Tagore: Selected Writings on Literature and Language, New Delhi: Oxford University Press, 1-21.

Datta, D. (2016). Translating Tagore in Serbia: Certain Inter-Cultural Perspectives (An Introduction). Philologia, 13/14, 105-118.

Eagleton, T. (1996). What is Literature? Literary Theory: An Introduction. Minneapolis: The University of Minnesota Press.

Gnoli, R. (1985). The Aesthetic Experience According to Abhinavagupta. Varanasi: Chowkhamba Sanskrit Series Office.

Higgins, K. M. (2007). An Alchemy of Emotion: Rasa and Aesthetic Breakthroughs. The Journal of Aesthetics and Art Criticism 65(1), 43-54.

Jameson, F. (1986). Third-World Literature in the Era of Multinational Capitalism. Social Text, 5(3), 65-88.

Russel, W. E. G. (ed.) (1900). Letters of Matthew Arnold 1848-1888. New York: The Macmillan Company. 
Said, E. W. (2006). Resistance, Opposition and Representation. In: B. Ashcroft et al. (eds.), The Postcolonial Studies Reader, London and York: Routledge, 95-98.

Said, E. W. (1994). Culture and Imperialism. New York: Vintage Books.

Sanyal, J. (2009). Postscripting Modernity. In: K. Sen and T. Gupta (eds.), Tagore and Modernity, Kolkata: Das Gupta and Co. Pvt. Ltd.

Tagore, R. (1889). Literature. In: S. K. Das and S. Chaudhuri (eds.), Rabindranath Tagore: Selected Writings on Literature and Language, New Delhi: Oxford University Press, 49-50.

Tagore, R. (1895). Bengali National Literature. In: S. K. Das and S. Chaudhuri (eds.), Rabindranath Tagore: Selected Writings on Literature and Language, New Delhi: Oxford University Press, 179-193.

Tagore, R. (1936). Sahityer Pathe (On the Roads to Literature). In: S. K. Das and S. Chaudhuri (eds.), Rabindranath Tagore: Selected Writings on Literature and Language, $1-21$.

Tagore, R. (2004). Sahitya. Kolkata: Visva-Bharati.

Tiffin, H. (2006). Postcolonial Literatures and Counter-Discourse. In: B. Ashcroft et al. (eds.), The Postcolonial Studies Reader, London and York: Routledge, 99-101. 